\title{
Synchronous Acute Appendicitis, Perforated Cecal Diverticulitis and Serrated Adenoma of Right-Sided Colon: An Uncommon Incidental Finding
}

\author{
Metin Yalaza, ${ }^{1}$ Mehmet Tolga Kafadar, ${ }^{2}$ Ahmet Türkan, ${ }^{3}$ \\ Gürkan Değirmencioğlu, ${ }^{4}$ Özgür Akgül ${ }^{5}$
}

'Department of General Surgery Division of Surgical Oncology Numune Training and Research Hospital, Ankara, Turkey

${ }^{2}$ Department of General Surgery, Health Sciences University Mehme Akif Inan Training and Research Hospital, Şanlıurfa, Turkey ${ }^{3}$ Department of General Surgery, Elbistan State Hospital, Kahramanmaraş, Turkey

${ }^{4}$ Department of General Surgery, Yıldırım Beyazıt University Faculty of Medicine, Ankara, Turkey

${ }^{5}$ Department of General Surgery, Numune Training and Research Hospital, Ankara, Turkey

Submitted: 27.07.2017 Accepted: 24.08 .2017

Corresp.: Mehmet Tolga Kafadar, Sağlık Bilimleri Üniversitesi Mehmet Akif İnan Eğitim ve Araştırma Hastanesi, Genel Cerrahi Kliniği, 63300 Şanlıurfa, Turkey

E-mail: drtolgakafadar@hotmail.com

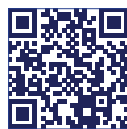

Keywords: Acute abdomen; acute appendicitis; cecal diverticulitis; serrated adenoma.

\begin{abstract}
Right iliac fossa pain is one of the most common reasons for a patient visit to the emergency department. Although appendicitis is the most common condition requiring surgery in patients with abdominal pain, right iliac fossa pain can be indicative of a vast list of differential diagnoses, and is thus both a diagnostic and a therapeutic challenge for clinicians. In this article, an exceedingly rare case of right iliac fossa pain in a 54-year-old male who had not just solitary perforated cecal diverticulitis, but also acute appendicitis and serrated adenoma of the ascending colon is presented. The final diagnosis was made by postoperative histopathological examination. To the best of our knowledge, this is the first reported case with these 3 different entities simultaneously present in the same patient.
\end{abstract}

\section{INTRODUCTION}

With respect to emergency surgery, the most common cause of right iliac fossa pain is acute appendicitis, but in rare instances it is possible to simultaneously also see an- other surgical pathology in the same patient. In such cases, although it is easier to make a decision about the necessity for surgery, it is more difficult, and almost impossible, to diagnose the pathology properly. ${ }^{[1]}$ Although cecal diverticulitis and acute appendicitis possess many dissimi- 

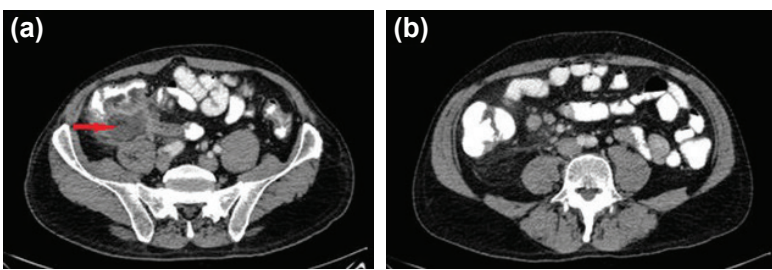

Figure 1. Multislice computed tomography image of the abdomen shows (a) wall thickening of the cecum mimicking a mass, inflamed appendix with phlegmon, and (b) enlarged mesenteric lymph nodes.

larities, they are both caused by a dead-end sac becoming obstructed and undergoing the processes of inflammation, abscess formation, and perforation. Hence, both diseases demonstrate some similarities in diagnosis and course of the disease. Synchronous presentation of acute appendicitis and perforated cecal diverticulitis is very rare, with only I case reported in literature. ${ }^{[2]}$ Simultaneous acute appendicitis, cecal diverticulitis, and serrated colon adenoma in the same patient has not previously been reported.

\section{CASE REPORT}

A 54-year-old man presented with the complaints of right lower abdominal pain, nausea, and vomiting ongoing for 5 days. There were no other gastrointestinal or genitourinary symptoms. The patient had no other relevant past medical history and had been well prior to this episode. Significant findings included local rebound tenderness and palpable fullness over the ileocecal region, leukocytosis, low-grade fever, and ultrasonographic evidence of acute appendicitis. Contrast-enhanced multislice computed tomography examination revealed mass-like wall thickening of the cecum and adjacent enflamed appendix with phlegmon, mesenteric lymphadenopathy, and paracolic fluid (Figure I). Radiographic and deteriorating abdominal signs led to the decision to proceed with surgical exploration. An emergency exploratory laparotomy via median incision was performed. Enflamed gangrenous cecum was found in surgery. As the diagnosis was not certain and a malignant formation was still a possibility, the operation included a right hemicolectomy. The postoperative period was uneventful and the patient was discharged on the ninth postoperative day. In addition to serrated adenoma of the ascending colon, pathology revealed a perforated solitary cecal diverticulum with surrounding inflammatory response and acute appendicitis (Figure 2). Informed consent for publication was obtained from the patient in this case.

\section{DISCUSSION}

A diverticulum is a bulging sac pushing outward from a hollow organ anywhere in the gastrointestinal tract from the esophagus to the colon. It is most common in the sigmoid colon. Diverticulum of the cecum is usually considered a relatively rare condition. As with diverticula elsewhere, those occurring in the cecum may be classed as either true or false. The prevalence of cecum diverticulum is higher in Oriental countries than in Western countries. ${ }^{[3,4]}$ In a review of $88 \mathrm{I}$ cases, Sardi et al. ${ }^{[5]}$ reported that prevalence of cecal diverticulum was $3.6 \%$. It may be asymptomatic or complicated by diverticulitis, bleeding, or perforation with peritonitis. Solitary cecal diverticulitis is difficult to differentiate from other causes of right iliac fossa pain, such as inflammatory bowel disease, gynecological or urological conditions, and appendicitis. According to Lane et al., ${ }^{[3]}$ in excess of $70 \%$ of patients with cecal diverticulitis were preoperatively diagnosed as having acute appendicitis. Since Potier described cecal diverticulitis in 1912, over 1000 cases have been reported in the literature. The reported incidence ranges between I:34 to $1: 300$ of that of appendicitis. ${ }^{[6]}$

The pathological mechanism of both solitary cecal diverticulitis and acute appendicitis is luminal obstruction, often by a fecolith; hence, the clinical presentation is identical: right lower quadrant abdominal pain, fever, and leukocytosis. It has been reported, however, that some indistinct
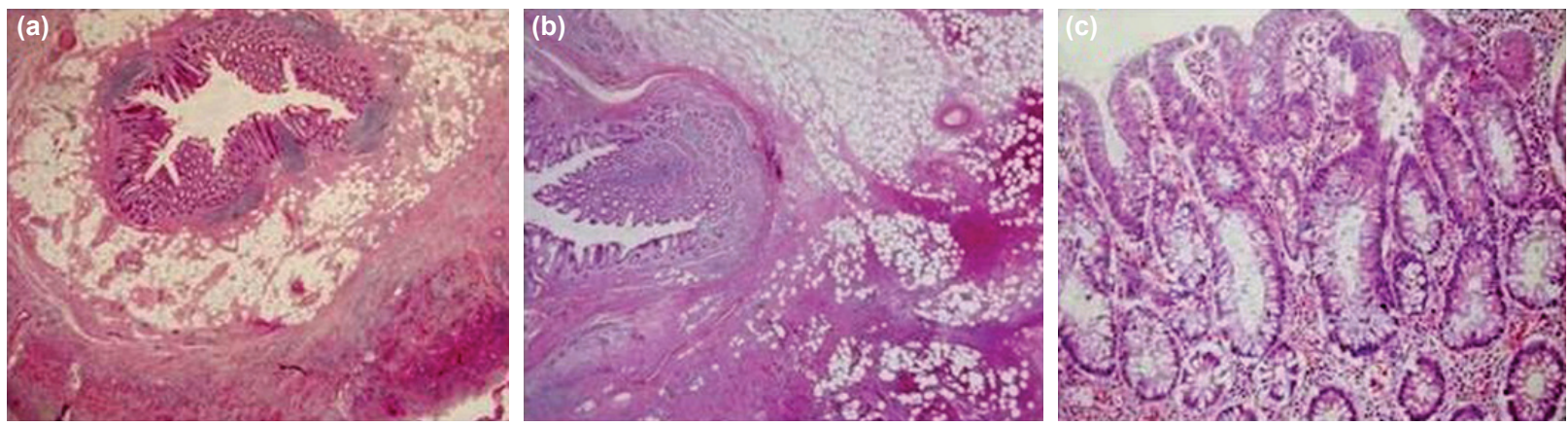

Figure 2. (a) Low-power microscopic view of the vermiform appendix with acute appendicitis and lymphoid follicles with prominent germinal centers and acute inflammation throughout the walls (H\&E, x20). (b) Perforated diverticulum with adjacent pericolonic abscess. The perforation of the diverticulum mucosa extends into the extramural fat (H\&E, x20). (c) Serrated adenoma with saw-toothed architecture and epithelial dysplasia (H\&E, x200). 
clinical clues may aid clinicians to differentiate between cecal diverticulitis and acute appendicitis, such as right iliac fossa pain persisting for a relatively long period of time in the absence of systemic toxicity, particularly with a lesion with posterior localization. ${ }^{[4]}$

In the presence of acute appendicitis, cecal diverticulitis, and serrated colon adenoma in the same patient, it is almost impossible to diagnose the clinical entity properly without using imaging and endoscopic modalities. Today, CT and ultrasonography are the most widely used imaging modalities in the differential diagnosis of pain in the right lower quadrant. It is a rare condition, albeit more frequent in Oriental societies, which is encountered in only 10 of 5000 radiological examinations. ${ }^{[7]}$

Chou et al., ${ }^{[8]}$ reported that the accuracy of ultrasound had a sensitivity of $91.3 \%$ and a specificity of $99.5 \%$ in diagnosing cecum diverticulitis, but this report has not been confirmed with other studies. With a reported sensitivity of $88 \%$ to $100 \%$ and a specificity of $91 \%$ to $99 \%$, computed tomography (CT) is the technique of choice at many centers for imaging evaluation of patients. ${ }^{[9]} \mathrm{CT}$ was performed in the present case; however, no specific finding related to diverticulitis or appendicitis was determined. Although acute appendicitis is one of the most frequent emergencies in general surgery, in our search of the literature we found only I report of acute appendicitis and cecal diverticulitis occurring simultaneously in the same patient. In addition to inflammation of both the caecum and the appendix, our patient had a serrated adenoma in the ascending colon. Longacre and Fenoglio-Preiser first described a serrated adenoma in 1990. Serrated polyps are a heterogeneous group of colon polyps, including hyperplastic polyps, sessile serrated adenomas, traditional serrated adenomas, and mixed polyps. Current evidence indicates that these lesions should be resected completely, and colonoscopy surveillance should be considered for the patient. ${ }^{[10]}$

In reality, these 3 entities may be impossible to differentiate from one another once inflammation occurs, and so excessive deliberation is not fruitful. Despite the use of diagnostic imaging, our case was not properly diagnosed preoperatively. According to a report by Wyble and Lee, ${ }^{\left[{ }^{1 I}\right]}$ correct preoperative diagnosis can only be made in $60 \%$ to $70 \%$ of cecal diverticulitis cases. Actually, even intraoperative diagnosis of cecal diverticulitis is not always clear, as in the case of our patient. The present case posed several challenges. First, the patient had more than I pathology to diagnose in the right iliac fossa. Second, the diagnosis was not made at the time of surgery, but a treatment decision had to be made intraoperatively. Furthermore, the patient had a polyp in the ascending colon.

Due to the absence of a randomized clinical trial that compares conservative and operative treatment, there is no consensus on the treatment of cecal diverticulitis. The available options range from conservative treatment with stand-alone antibiotics to extensive, aggressive surgical resection. If a solitary cecal diverticulum is clearly identified at the time of surgery, some authors advocate no intervention, while others recommend a simple diverticulectomy, or at least invagination of the diverticulum combined with appendectomy. ${ }^{[2]}$ In the presence of marked inflammatory changes or complications, such as free perforation, torsion, or localized abscess formation, ileocecal resection or right hemicolectomy should be considered. ${ }^{[13]}$ Yang et al., ${ }^{[14]}$ reported that if perioperative malignancy was suspected, right hemicolectomy is the treatment of choice. Fang et al., ${ }^{[15]}$ recommended an aggressive resection in treatment of the disease because $29 \%$ of the patients undergoing only an appendectomy in their study had recurrent episodes of right diverticulitis, and $12.5 \%$ of them required subsequent right hemicolectomy.

\section{Conclusion}

Acute appendicitis is the most common operative pathology in general surgery. On the other hand, cecal diverticulitis and serrated adenoma of the colon are rare conditions. The simultaneous presence of all 3 of these pathologies in the same patient was a very rare event. Clinical, radiological, and operative features of diseases may mimic each other and/or may overlap, and in such a case, the clinician is confronted with a diagnostic dilemma. Hence, when faced with multiple, synchronous, pathological conditions, cecal phlegmon, or when malignancy cannot be ruled out in a situation such as ours, aggressive resection may be performed.

\section{Informed Consent}

Informed consent was obtained from the patient in this case.

\section{Peer-review}

Internally peer-reviewed.

Authorship Contributions

Surgical and Medical Practices: M.Y., M.T.K.; Concept: M.Y., M.T.K., A.T., G.D.; Design: M.Y., M.T.K., G.D.; Data collection \&/or processing: M.Y., Ö.A.; Analysis and/or interpretation: M.Y., A.T., G.D., Ö.A.; Literature search: M.Y., M.T.K., A.T.; Writing: M.Y., M.T.K.; Critical review: M.T.K., A.T., Ö.A.

\section{Conflict of Interest}

None declared.

Financial Disclosure

The authors declared that this study has received no financial support.

\section{REFERENCES}

1. Kalcan S, Başak F, Hasbahçeci M, Kilıç A, Canbak T, Kudaş İ, et al. Intraoperative diagnosis of cecal diverticulitis during surgery for acute 
appendicitis: Case series. Ulus Cerrahi Derg 2015;32:54-7.

2. Karaca G, Tekten G, Güler O, Kuşabbi R, Köklü S, Ustün H, et al. Acute appendicitis and cecal diverticulitis in a young woman. Emerg Med Australas 2010;22:192-3. [CrossRef]

3. Lane JS, Sarkar R, Schmit PJ, Chandler CF, Thompson JE Jr. Surgical approach to cecal diverticulitis. J Am Coll Surg 1999;188:629-34.

4. Shyung LR, Lin SC, Shih SC, Kao CR, Chou SY. Decision making in right-sided diverticulitis. World J Gastroenterol 2003;9:606-8.

5. Sardi A, Gokli A, Singer JA. Diverticular disease of the cecum and ascending colon. A review of 881 cases. Am Surg 1987;53:41-5.

6. Oudenhoven LF, Koumans RK, Puylaert JB. Right colonic diverticulitis: US and CT findings-new insights about frequency and natural history. Radiology 1998;208:611-8. [CrossRef]

7. Lane MJ, Liu DM, Huynh MD, Jeffrey RB Jr, Mindelzun RE, Katz DS. Suspected acute appendicitis: nonenhanced helical CT in 300 consecutive patients. Radiology 1999;213:341-6. [CrossRef]

8. Chou YH, Chiou HJ, Tiu CM, Chen JD, Hsu CC, Lee CH, et al. Sonography of acute right side colonic diverticulitis. Am J Surg 2001;181:122-7. [CrossRef]

9. Rao PM, Rhea JT, Novelline RA, Mostafavi AA, Lawrason JN, Mc-
Cabe CJ. Helical CT combined with contrast material administered only through the colon for imaging of suspected appendicitis. AJR Am J Roentgenol 1997;169:1275-80. [CrossRef]

10. Longacre TA, Fenoglio-Preiser CM. Mixed hyperplastic adenomatous polyps/serrated adenomas. A distinct form of colorectal neoplasia. Am J Surg Pathol 1990;14:524-37. [CrossRef]

11. Wyble EJ, Lee WC. Cecal diverticulitis: changing trends in management. South Med J 1988;81:313-6. [CrossRef]

12. Mudatsakis N, Nikolaou M, Krithinakis K, Matalliotakis M, Politis $\mathrm{N}$, Andreadakis E. Solitary cecal diverticulitis: an unusual cause of acute right iliac fossa pain-a case report and review of the literature. Case Rep Surg 2014;2014:131452. [CrossRef]

13. Guven H, Koc B, Saglam F, Bayram IA, Adas G. Emergency right hemicolectomy for inflammatory cecal masses mimicking acute appendicitis. World J Emerg Surg 2014;9:7. [CrossRef]

14. Yang HR, Huang HH, Wang YC, Hsieh CH, Chung PK, Jeng LB, et al. Management of right colon diverticulitis: a 10-year experience. World J Surg 2006;30:1929-34. [CrossRef]

15. Fang JF, Chen RJ, Lin BC, Hsu YB, Kao JL, Chen MF. Aggressive resection is indicated for cecal diverticulitis. Am J Surg 2003;185:13540. [CrossRef]

\section{Senkronize Akut Apandisit, Çekum Divertikül Perforasyonu ve Sağ Kolon Serrated Adenomu: Nadir Bir Rastlantısal Bulgu}

Karın sağ alt kadran ağrısı, bir hastanın acil servise başvurmasının en yaygın nedenlerinden biridir. Apandisit, karın ağrısı olan hastalarda ameliyat gerektiren en sık durumlardan biri olmasına rağmen, sağ alt kadran ağrısı geniş bir ayrıcı tanı yelpazesi içerir ve bu durum hekimler için tanı ve tedavide zorluklar oluşturabilir. Bu yazıda, sağ alt kadran ağrısının oldukça nadir bir sebebi olarak sadece perfore çekum divertikülü değil, eş zamanlı akut apandisit ve çıkan kolonun serrated adenomunun bulunduğu 54 yaşında erkek bir hasta sunuldu. Hastada kesin tanı ameliyat sonrası histopatolojik inceleme ile konuldu. Bilgilerimiz dahilinde bu olgu, aynı hastada bu üç farklı klinik tablonun eş zamanlı bulunduğu, bildirilmiş ilk olgudur.

Anahtar Sözcükler: Akut apandisit; akut karın; çekal divertikülit; serrated adenoma. 